\title{
Foreign Aid and Economic Growth: Panel Cointegration Analysis for Cambodia, Lao PDR, Myanmar, and Vietnam
}

\author{
By Pahlaj Moolio* \\ Somphyvatanak Kong ${ }^{\dagger}$
}

\begin{abstract}
Given the paradoxical results of impact studies of foreign aid on economic growth in aid-growth literature, the effectiveness of aid for growth still remains a subject of intense debate. Thus, applying panel cointegration tests, and panel fully modified ordinary least squares (FMOLS) and panel dynamic ordinary least squares (DOLS) estimators, this paper estimates the magnitude of long run relationship between aid and economic growth in Cambodia, Lao PDR, Myanmar, and Vietnam using panel data from 1997 to 2014. The results of panel cointegration tests revealed that aid and economic growth cointegrate in a panel framework for the period of the study, indicating a robust long run relationship between the variables. Panel FMOLS and Panel DOLS estimation results revealed a positive impact of aid on economic growth. Thus, study concludes that foreign aid has a favorable effect on economic growth in the sample of four countries from ASEAN region.
\end{abstract}

Keywords: Foreign Aid, Economic Growth, Panel Cointegration, Panel FMOLS, Panel DOLS.

\section{Introduction}

Economic growth has been used as one of the strategies for poverty reduction in developing countries. For economic growth, capital is considered as one of the important macroeconomic factors. Foreign aid or official development assistance (ODA) is referred to as the international transfer of capital, goods, or services from developed countries or multinational organizations to developing countries for the benefit of the recipient countries or their populations. Thus, foreign aid has been a significance source of income (capital) for many developing countries around the world (Pallage and Robe 2001).

It is undeniably true that- large amounts of capital are transferred to developing countries with the purpose to eradicate extreme poverty and promote inclusive economic growth, through assistance programs for agriculture, health, family planning, education, environment, and democracy and governance. However, the contribution of foreign aid to the economic growth of developing countries could be positive, negative, or even nonexistent, in statistical terms (Moreira 2005). The question whether foreign aid enhances economic growth in aid-recipient countries still remains highly debated, and no consensus is found among researchers and policy makers

\footnotetext{
* Professor, Pannasastra University of Cambodia, Cambodia.

${ }^{\dagger}$ Researcher, Pannasastra University of Cambodia, Cambodia.
} 
(Veiderpass and Andersson, 2007). In the aid-growth literature, there has been an abundance of empirical studies on impact of aid on economic growth with mixed findings (Heng and Moolio 2015). Hence, many authors point towards the value of a continued research in this field.

Cambodia, Lao PDR, Myanmar, and Vietnam (CLMV) have received approximately US\$68.6 billion in foreign aid during the study period from 1997 to 2014, with Vietnam the largest recipient followed by Cambodia, Myanmar, and Lao PDR From the graph (Figure 1), by comparing foreign aid as share of GDP, Lao PDR has been the most aid-dependent among the four, followed by Cambodia, Vietnam, and Myanmar during the study period; however, overall dependency of CLMV on foreign aid has been declining. As depicted in graph (Figure 2), all of the four countries in the sample have demonstrated spectacular economic performance during the study period, and have achieved impressive annual GDP growth. More specifically, Cambodia achieved annual average growth rate of $7.84 \%$, Lao PDR at $6.92 \%$, Myanmar at $10.61 \%$, and Vietnam at $6.38 \%$ during the study period from 1997 to 2014 .

Therefore, the question is raised whether foreign aid has any statistically significant impact on these countries' economic growth. As the major recipients of foreign aid in ASEAN region, CLMV are neighbouring countries and located in the ASEAN region with similar socio-economic conditions. Thus, the aim of this paper is to explore and estimate quantitatively the magnitude of the long run relationship between foreign aid and economic growth in Cambodia, Lao PDR, Myanmar, and Vietnam for the panel data from 1997 to 2014.

Figure 1. Foreign Aid as a Share of GDP in CLMV (1997-2014)

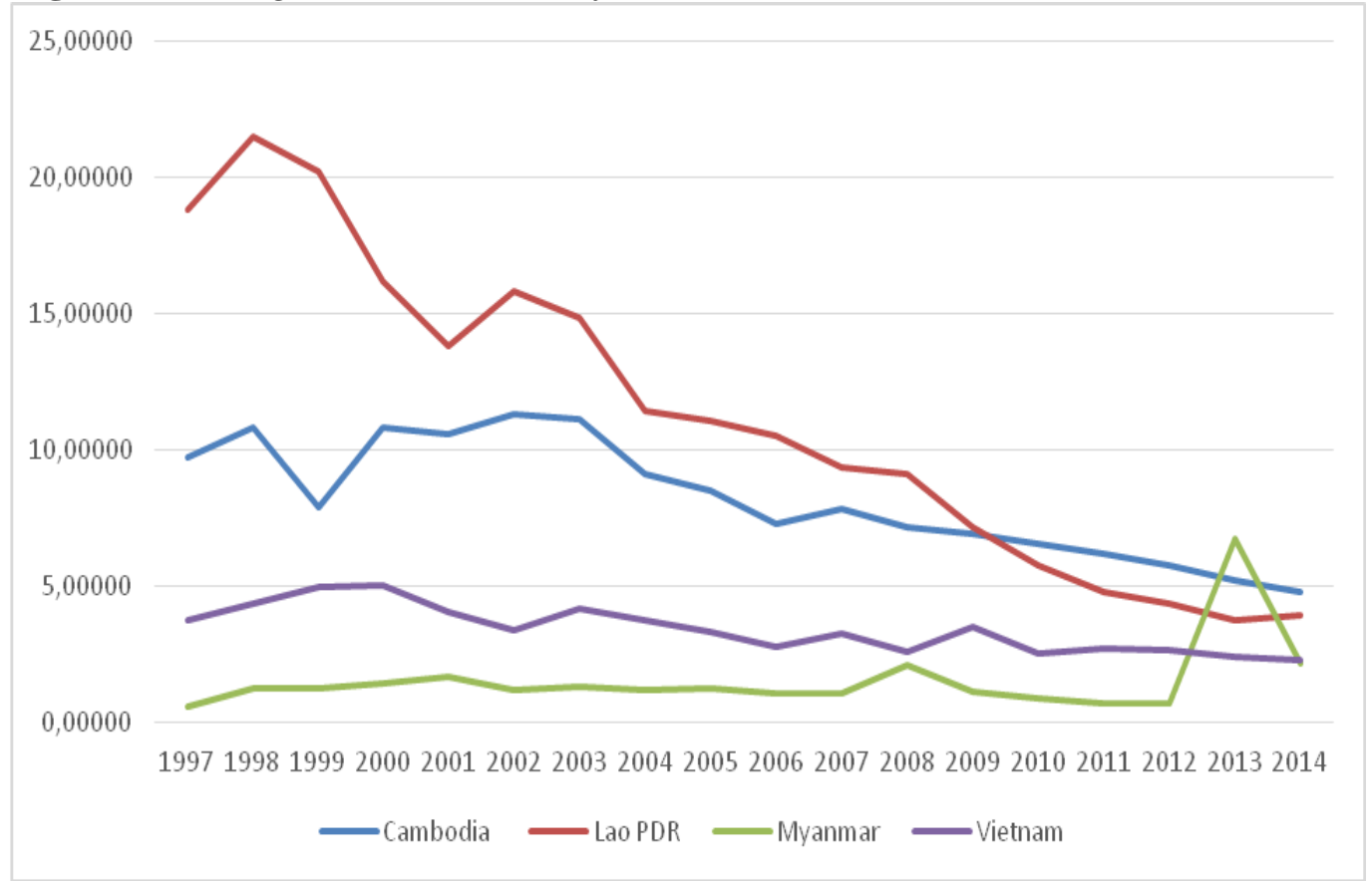

Source: Author's calculation. 
Figure 2. CLMV's Annual GDP Growth (\%) (1997-2014)

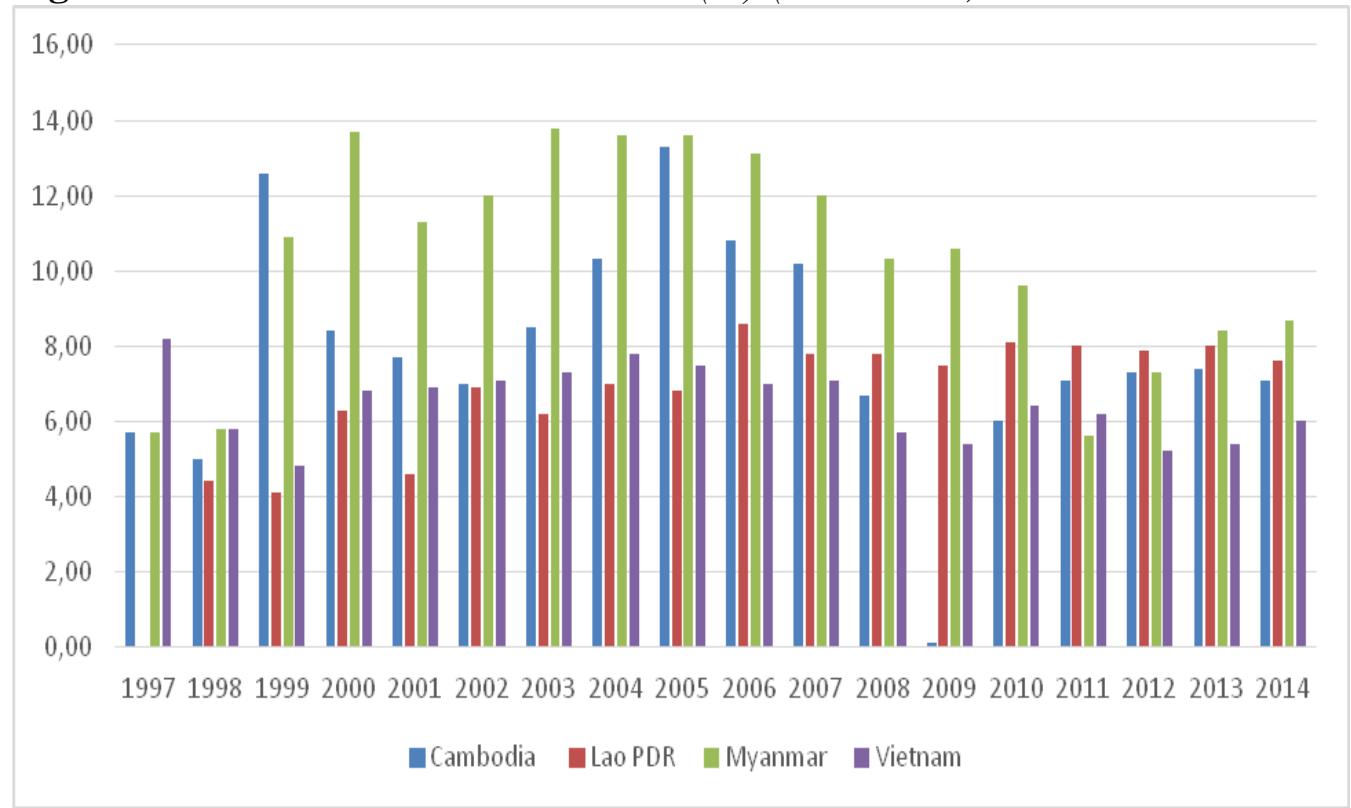

Source: Author's calculation.

With this introduction, the remainder of the paper is structured as follows: In Section 2, a review of related literature is presented, followed by data and econometric methodology in Section 3. Section 4 contains empirical results, analysis and interpretations, whereas Section 5 includes conclusion and recommendations. In this paper, the technical and mathematical details are kept to a minimum.

\section{Literature Review}

Foreign aid or official development assistance (ODA) consists of disbursements of loans made on concessional terms (net of repayments of principal) and grants by official agencies of the members of the Development Assistance Committee (DAC), by multilateral institutions and by non-DAC countries to promote economic development and welfare in countries and territories in the DAC list of ODA recipients (The World Bank 2014). A developing countries face difficulties related to finance and savings gaps, foreign aid or official development assistance is provided to them to bridge such gaps. Adam Smith's capital accumulation, Rostow's “stages of growth", and Harrod-Domar growth model underscore the role that foreign aid can play in stimulating economic growth.

Adam Smith (1776), and Winch (2013) (nothing in-between?) greatly emphasized the strategic role of capital accumulation as a prerequisite for economic growth. Smith suggests that the key to the growth of labour productivity is the division of labour which in turn depends on the extent of the market and thus upon capital accumulation. Smith stated that any increase in 
the capital stock in a country generally leads to more than a proportional increase in the output on the account of constantly growing division of labour.

Furthermore, Walt Whitman Rostow (1960) argued that the transition from underdevelopment to development can be described in terms of a series of steps or stages through which all countries must go through. He stated that push for the initial development of only one or two sectors over the development of all sectors is equally important. One of the principal strategies of development necessary for any takeoff is the mobilization of domestic and foreign savings in order to generate sufficient investment to accelerate economic growth.

Likewise, Harrod (1939), Domar (1946), and Cheung (2013) stated that the rate of economic growth in an economy is dependent on the level of savings and on the capital output ratio. With Smith's ideas, Rostow's arguments, and Harrod-Domar growth model in mind, the role of foreign aid comes into play because developing countries are constrained with savings and capital. Thus, foreign aid provides developing countries with the capital for investment.

The empirical aid-growth literature, contains controversial or mixed evidence with regards to the effectiveness of foreign aid on economic growth. Chenery and Strout (1966) and Papanek (1973), in their investigations into the role of foreign aid on economic growth, asserted that foreign aid helps in reducing the foreign exchange gap, provides access to modern technology and managerial skills, and grants easy access to foreign markets. Similar findings are replicated by Gulati (1978), Gupta (1975), Over (1975), Levy (1988), and Islam (1992) as cited by Hatemi-J and Irandoust (2005), among others. Also, Veiderpass \& Andersson (2007), Karras (2006), and Mitra (2013), covering a range of developing countries, found that the effects of foreign aid on economic growth are positive, statistically significant in the long-run, and not negligible in size.

However, there are other studies which reveal that the foreign aid rather than complementing or adding to domestic savings/resources is fully consumed and substituted, inappropriate technology is imported, domestic income distribution is distorted, and to compound the problems, a bigger, inefficient and corrupt government is encouraged in aid-recipient countries (Griffin 1970; Griffin and Enos 1970; Weisskof 1972; Boone 1996; and Easterly 2003).

Even more interestingly, Burnside and Dollar (2000) demonstrate that foreign aid has a positive impact on economic growth in aid-recipient countries with good fiscal, monetary, and trade policies but little effect or no effect in the presence of poor policies. Moreover, Collier and Dollar (2002), by using a different data set, validated the findings of Burnside and Dollar (2000) and concluded that the effect of aid on poverty depends on the quality of policies. Authors argue that to increase growth and reduce poverty, it would be more effective and efficient to direct aid to countries that have good policies. On the other hand, Montinola (2007), testing data from 67 countries over the period from 1980 to 1999, shows that aid promotes fiscal reform, but only in more democratic countries, and the positive impact of aid on reform increases with 
level of democracy. Whereas, Dalgaard \& Hansen (2001), Hansen \& Tarp (2001), and Jensen \& Paldam (2003) found that aid does increase the growth rate ${ }_{2}$ but surprisingly it is not conditional on "good policy" as argued by Burnside and Dollar (2000), Collier and Dollar (2002), and Montinola (2007).

From a review of empirical literature on foreign aid and economic growth, it has so far been revealed that there are inconsistent and somewhat very controversial results in relation to the effects of foreign aid on economic growth. This motivates us to conduct this study on four developing countries for the sample from ASEAN block to investigate whether aid has any effect on these countries economic growth.

\section{Methodology}

The scope of this paper covers the period from 1997 to 2014 and conducts analysis in four countries from ASEAN region, specifically Cambodia, Lao PDR, Myanmar, and Vietnam (CLMV). The variables of interest are: real GDP as proxy for economic growth, and foreign aid inflows to the CLMV. Panel data of annual frequency is used. Data of foreign aid expressed in US dollars was extracted from databank of the World Bank, while the data on GDP are from Key Indicators for Asia and Pacific of the Asian Development Bank. Following Hatemi-J and Irandoust (2005), we deflated GDP series by using each country's consumer price index of that year. The common logarithm forms of the variables have been used for the purpose of the stability of the data. The aim of this study is to test and estimate the cointegrating long run relationship between foreign aid and economic growth, as well as magnitude of impact of aid on economic growth in CLMV.

This study makes use of the Hatemi-J and Irandoust (2005) model specification, applying panel cointegration methods. The model is defined as below:

$$
\operatorname{LogGDP}_{i t}=\alpha_{i}+\beta_{\mathrm{i}} \log \mathrm{Aid}_{i t}+\varepsilon_{\mathrm{it}} \quad \text { for } \mathrm{i}=1, \ldots, \mathrm{N} \text { and } \mathrm{t}=1, \ldots, \mathrm{T} \text {, }
$$

where $\log \mathrm{GDP}_{\text {it }}$ denotes the common logarithm form of real Gross Domestic Product (GDP) for the country $i$ at time $t, \log$ Aid $_{i t}$ is the common logarithm form of net foreign aid (or official development assistance) to country $i$ at time $\mathrm{t}$, and $\varepsilon_{\mathrm{it}}$ is the stochastic error term for the country $\mathrm{i}$, at time $\mathrm{t}$.

To estimate the Equation (1) as a panel cointegration model, we first need to check non-stationarity and long run cointegration of the variables considered in the model (Sahin and Cengiz 2011). Thus, the empirical analysis of foreign aid and economic growth is carried out in three stage process in this paper. Firstly, we assess the order of the integration for the variables to determine whether foreign aid and GDP as variables are non-stationary (existence of unit root) at level and stationary (no existence of unit root) at first difference, because this is a precondition for applying panel cointegration tests to explore the cointegrating relationship between foreign aid and economic growth in the 
long run. For this purpose, various panel unit root tests are performed. Secondly, we apply residual-based panel cointegration tests of both Pedroni (1999) and Kao (1999) to determine whether a long run cointegrating relationship exists between the foreign aid and economic growth. Finally, we apply panel fully modified ordinary least squares (FMOLS) approach (Pedroni 1997, 1999, 2000) and the panel dynamic ordinary least squares (DOLS) approach (Stock and Watson 1993, and Kao and Chiang 2000) to estimate the magnitude of the long run relationship between the variables considered for the sample of four countries in the ASEAN region. Both panel FMOLS and DOLS methods are bias-corrected approaches. The panel DOLS estimator is outperforming the FMOLS estimator (Kao and Chiang 2000); thus, DOLS has super small sample properties (Lee 2007) and it will confirm the results obtained by FMOLS estimator. All the calculations for various panel unit root tests, cointegration tests, and FMOLS and DOLS estimations are carried out through EViews version 8 Statistical Software.

\section{Results and Analysis}

The panel unit root test types included are common root - Levin, Lin, Chu (2002) and Breitung (2000); individual root - Im, Pesaran, Shin (2003), FisherADF and Fisher-PP. The optimal lags of the ADF and PP test models were automatically selected by Schwarz Information Criterion (SIC) and the NeweyWest automatic bandwidth and Bartlett kernel. The null hypothesis of all test methods considered here is that the panel data has a unit root, meaning that the variables are non-stationary, and the alternative hypothesis is that the panel data has no unit root, meaning that the variables considered in the study are stationary.

Table 1, and Table 2 report the summary of the various test results of the panel unit root: individual effect, individual effects and individual linear trend, and none, at level and at first difference. In the case of GDP (Table 1), we can see that the probabilities (p-values) of the majority of the test statistics are more than 5\% at level; therefore, we cannot reject the null hypothesis of unit root, meaning that panel GDP series has a unit root (non-stationary) at level. While this is also the case for AID series, the probabilities (p-values) of most of the test statistics are more than 5\% at level; so we cannot reject the null hypothesis of unit root, meaning that panel AID series has a unit root (nonstationary) at level. This implies that there is a unit root at level in both the series, i.e., both the GDP and the AID series are non-stationary at level. 
Table 1. Results of Panel Unit Root Tests for LogGDP

\begin{tabular}{|c|c|c|c|}
\hline Method & Individual intercept & $\begin{array}{c}\text { Individual intercept and } \\
\text { trend }\end{array}$ & None \\
\hline $\begin{array}{l}\text { Level } \\
\text { Levin, Lin \& Chu t } \\
\text { Breitung t-stat } \\
\text { Im, Pesaran and Shin W-stat } \\
\text { ADF - Fisher Chi-square } \\
\text { PP - Fisher Chi-square } \\
\text { First difference } \\
\text { Levin, Lin \& Chu t } \\
\text { Breitung t-stat } \\
\text { Im, Pesaran and Shin W-stat } \\
\text { ADF - Fisher Chi-square } \\
\text { PP - Fisher Chi-square }\end{array}$ & $\begin{array}{c}-11.0250^{*} \\
(0.0000) \\
\\
-8.7581^{*} \\
(0.0000) \\
67.1431^{*} \\
(0.0000) \\
119.103^{*} \\
(0.0000)\end{array}$ & $\begin{array}{c}-7.2317^{*} \\
(0.0000) \\
-1.0017 \\
(0.1582) \\
-5.8165^{*} \\
(0.0000) \\
37.2822^{*} \\
(0.0000) \\
36.2725^{*} \\
(0.0000)\end{array}$ & $\begin{array}{c}0.6107 \\
(0.9997) \\
0.3663 \\
(1.000)\end{array}$ \\
\hline
\end{tabular}

Source: Author's calculation using E-views software. LEGEND: a) * indicates that Statistic is significant at 5\% significance level. b) Numbers in parenthesis are p-values for corresponding Statistic.

However, in the first differenced form (Table 1 and Table 2), we found that both the GDP and the AID series are stationary, as the outcomes of the probabilities (p-values) are less than 5\% significance level, therefore we can reject the null hypothesis of unit root, and accept the alternative hypothesis of no unit root, meaning that both the GDP and AID series became stationary at the first difference.

Having the non-stationary (existence of unit root) data series at level for both the GDP and AID series, and the stationary (no existence of unit root) at the first differenced, we proceed to derive both Pedroni (1999), and Kao (1999) cointegration tests results. Automatic lag length selection is based on Schwarz Information Criterion (SIC) and the Newey-West bandwidth and Bartlett kernel. The null hypothesis for both the Pedroni's and the Kao's tests is that there is no cointegration in the series, and the alternative hypothesis is that there is cointegration in the series. Table 3 and Table 4 report the results of the panel cointegration tests to see whether GDP and AID series cointegrate in panel perspective.

The Pedroni approach (Table 3) tests variables separately, calculating in-group and among-groups statistics. Meaningful statistical estimates derived from Panel v (Variance ratio), Panel $\rho$ (Phillips-Perron Type $\rho$ ), Panel PP (Phillips-Perron Type t) and Panel ADF (Dickey-Fuller Type t) are used for in-group statistics; while Group $\rho$ - (Phillips-Perron Type $\rho$ ), Group PP -(Phillips-Perron Type t) and Group ADF (Dickey-Fuller Type t) are used in among-group statistics to verify the cointegration relation between the variables. 
Table 2. Results of Panel Unit Root Tests for LogAID

\begin{tabular}{|c|c|c|c|}
\hline Method & Individual intercept & $\begin{array}{l}\text { Individual intercept and } \\
\text { trend }\end{array}$ & None \\
\hline $\begin{array}{l}\text { Level } \\
\text { Levin, Lin \& Chu t } \\
\text { Breitung t-stat } \\
\text { Im, Pesaran and Shin W-stat } \\
\text { ADF - Fisher Chi-square } \\
\text { PP - Fisher Chi-square } \\
\text { First difference } \\
\text { Levin, Lin \& Chu t } \\
\text { Breitung t-stat } \\
\text { Im, Pesaran and Shin W-stat } \\
\text { ADF - Fisher Chi-square } \\
\text { PP - Fisher Chi-square }\end{array}$ & $\begin{array}{c}0.3140 \\
(0.6233) \\
\\
1.9724 \\
(0.9757) \\
1.6932 \\
(0.9890) \\
1.9258 \\
(0.9832)\end{array}$ & $\begin{array}{c}-2.9552 * \\
(0.0016) \\
-2.0733 * \\
(0.0191) \\
-1.8192 * \\
(0.0344) \\
14.7916 \\
(0.0633) \\
14.8256 \\
(0.0626)\end{array}$ & $\begin{array}{c}68.1526^{*} \\
(0.0000) \\
68.2089 * \\
(0.0000)\end{array}$ \\
\hline
\end{tabular}

Source: Author's calculation through E-views 8 Software. LEGEND: a) * indicates that Statistic is significant at $5 \%$ significance level. b) Numbers in parenthesis are p-values for corresponding Statistic.

Table 3. Results of Pedroni's Residual Cointegration Test for LogGDP $\log A I D$

\begin{tabular}{|c|c|c|c|c|c|c|}
\hline & \multicolumn{2}{|c|}{$\begin{array}{l}\text { No deterministic } \\
\text { trend }\end{array}$} & \multicolumn{2}{|c|}{$\begin{array}{c}\text { Deterministic } \\
\text { intercept and trend }\end{array}$} & \multicolumn{2}{|c|}{$\begin{array}{l}\text { No deterministic } \\
\text { intercept or trend }\end{array}$} \\
\hline $\begin{array}{l}\text { Alternative hypothesis: } \\
\text { common AR coefs. }\end{array}$ & \multicolumn{6}{|c|}{ (within-dimension) } \\
\hline Test Method & $\begin{array}{l}\text { Statistic } \\
\text { (Prob.) }\end{array}$ & $\begin{array}{l}\text { Weighted } \\
\text { Statistic } \\
\text { (Prob.) }\end{array}$ & $\begin{array}{l}\text { Statistic } \\
\text { (Prob.) }\end{array}$ & $\begin{array}{l}\text { Weighted } \\
\text { Statistic } \\
\text { (Prob.) }\end{array}$ & $\begin{array}{l}\text { Statistic } \\
\text { (Prob.) }\end{array}$ & $\begin{array}{l}\text { Weighted } \\
\text { Statistic } \\
\text { (Prob.) }\end{array}$ \\
\hline Panel v-Statistic & $\begin{array}{c}0.3459 \\
(0.3647) \\
\end{array}$ & $\begin{array}{c}0.8852 \\
(0.1880) \\
\end{array}$ & $\begin{array}{l}-0.4650 \\
(0.6791) \\
\end{array}$ & $\begin{array}{c}0.7334 \\
(0.2316) \\
\end{array}$ & $\begin{array}{c}1.0213 \\
(0.1535) \\
\end{array}$ & $\begin{array}{l}1.6875^{*} \\
(0.0457) \\
\end{array}$ \\
\hline Panel rho-Statistic & $\begin{array}{l}-1.2929 \\
(0.0980)\end{array}$ & $\begin{array}{l}-1.6116 \\
(0.0535)\end{array}$ & $\begin{array}{l}-0.2600 \\
(0.3974)\end{array}$ & $\begin{array}{l}-0.9549 \\
(0.1698)\end{array}$ & $\begin{array}{l}-1.7201^{*} \\
(0.0427)\end{array}$ & $\begin{array}{l}-1.5906 \\
(0.0558)\end{array}$ \\
\hline Panel PP-Statistic & $\begin{array}{l}-1.9996^{*} \\
(0.0228)\end{array}$ & $\begin{array}{l}-2.3667^{*} \\
(0.0090)\end{array}$ & $\begin{array}{l}-2.4338^{*} \\
(0.0075)\end{array}$ & $\begin{array}{l}-3.4438^{*} \\
(0.0003)\end{array}$ & $\begin{array}{l}-2.0252 * \\
(0.0214)\end{array}$ & $\begin{array}{l}-1.8446^{*} \\
(0.0325)\end{array}$ \\
\hline Panel ADF-Statistic & $\begin{array}{l}-2.5274^{*} \\
(0.0057) \\
\end{array}$ & $\begin{array}{l}-3.0583^{*} \\
(0.0011) \\
\end{array}$ & $\begin{array}{l}-2.2452^{*} \\
(0.0124) \\
\end{array}$ & $\begin{array}{l}-3.7872^{*} \\
(0.0001) \\
\end{array}$ & $\begin{array}{l}-2.0604^{*} \\
(0.0197) \\
\end{array}$ & $\begin{array}{l}-1.9387^{*} \\
(0.0263) \\
\end{array}$ \\
\hline $\begin{array}{l}\text { Alternative hypothesis: } \\
\text { individual AR coefs. }\end{array}$ & \multicolumn{6}{|c|}{ (between-dimension) } \\
\hline Group rho-Statistic & $\begin{array}{l}-0.7039 \\
(0.2407)\end{array}$ & & $\begin{array}{l}-0.3321 \\
(0.3699)\end{array}$ & & $\begin{array}{l}-0.7502 \\
(0.2265)\end{array}$ & \\
\hline Group PP-Statistic & $\begin{array}{l}-2.3550^{*} \\
(0.0093)\end{array}$ & & $\begin{array}{l}-3.6921^{*} \\
(0.0001)\end{array}$ & & $\begin{array}{l}-2.6176^{*} \\
(0.0044)\end{array}$ & \\
\hline Group ADF-Statistic & $\begin{array}{l}-3.4314^{*} \\
(0.0003)\end{array}$ & & $\begin{array}{l}-5.3210^{*} \\
(0.0000)\end{array}$ & & $\begin{array}{l}-3.3769^{*} \\
(0.0004)\end{array}$ & \\
\hline
\end{tabular}

Source: Author's calculation through E-views 8 Software. LEGEND: a) Numbers in parenthesis are p-values for corresponding Statistic. b) * indicates that Statistic is significant at 5\% significance level. 
Based on the results of Pedroni (1999) test (Table 3) majority of the outcomes are significant at 5\% level of significance. Therefore, we can reject the null hypothesis of no cointegration, and accept the alternative hypothesis of cointegration, meaning that foreign aid and GDP are co-integrated in a panel framework. The result of Kao (1999) test (Table 4) also results in p-values close to $5 \%$; therefore we can reject the null hypothesis of no cointegration, and accept the alternative hypothesis of cointegration. Therefore, foreign aid and GDP are co-integrated in a panel framework. The results of the both Pedroni's test and Kao's test are in agreement. Thus, it can be concluded that the aid and economic growth have robust long-run association in CLMV countries.

Table 4. Results of Kao's Residual Cointegration Test for LogGDP LogAID

\begin{tabular}{|c|c|c|}
\hline & t-Statistic & Prob. \\
\hline $\mathrm{ADF}$ & -1.619685 & 0.0527 \\
\hline
\end{tabular}

Source: Author's calculation through E-views 8 Software.

Given the evidence of cointegration between foreign aid and economic growth at 5\% significance level, we are in position to proceed further to estimate the magnitude of the long run relationship between the variables by applying panel Fully Modified Ordinary Least Squares (FMOLS) and panel Dynamic Ordinary Least Squares (DOLS) estimators. We do so for CLMV as a group (Table 5), as well as for country specific (Table 6).

Table 5. Results of FMOLS and DOLS for CLMV as a group

\begin{tabular}{|l|l|l|l|l|l|}
\hline \multicolumn{6}{|l|}{ Dependent Variable: LOG_GDP } \\
\hline & Variable & Coefficient & Std. Error & t-Statistic & Prob. \\
\hline FMOLS & LOG_AID & 0.912939 & 0.004800 & 190.1971 & 0.0000 \\
\cline { 3 - 6 } & & 0.913310 & 0.004999 & 182.7145 & 0.0000 \\
\hline
\end{tabular}

Source: Author's calculation through E-views 8 Software.

Table 6. Country Specific Results of FMOLS and DOLS

\begin{tabular}{|l|l|l|l|l|}
\hline & Cambodia & Lao PDR & Myanmar & Vietnam \\
\hline FMOLS & 0.8900031 & 0.865451 & 0.952816 & 0.943459 \\
\hline DOLS & 0.888497 & 0.865994 & 0.955730 & 0.943019 \\
\hline
\end{tabular}

Source: Author's calculations through E-views software.

From Table 5, the signs of the coefficient of AID for both FMOLS and DOLS estimators are positive and the t-Statistic is significant at all conventional significance levels, as p-values are less than $10 \%, 5 \%$ and $1 \%$ significance levels. These results statistically indicate that, other things being equal, the foreign aid inflows have a positive and significant impact on the real GDP in Cambodia, Lao PDR, Myanmar, and Vietnam as a group. More specifically, the co-efficient of AID obtained through panel FMOLS is 0.912939; while the co-efficient obtained from panel DOLS estimator is 0.913310; that is, both the panel FMOLS and panel DOLS estimated results are 
in agreement. This is a grouped estimation, which implies that 10 units of foreign aid inflows to Cambodia, Lao PDR, Myanmar, and Vietnam resulted in about 9.1 units increase in real GDP in CLMV as in group. The results obtained in this study are consistent with the study conducted by Hatemi-J and Irandoust (2005) on Swedish aid to Botswana, Ethiopia, India, Kenya, Sri Lanka, and Tanzania with sample period of 1974 to 1996. Moreover, looking at country specific results (Table 6), Myanmar has benefited most from foreign aid, followed by Vietnam, Cambodia, and Lao PDR.

\section{Conclusion and Recommendations}

Many empirical studies in aid-growth literature, exploring the effectiveness of aid on economic growth in many aid-recipient countries, found mixed or inconclusive results; therefore, an attempt was made in this study to explore the effectiveness of foreign aid on economic growth in four countries in ASEAN region. All the statistical evidence and empirical inferential results obtained indicate that the foreign aid and GDP cointegrate in panel perspective during the period of study in Cambodia, Lao PDR, Myanmar, and Vietnam. It can be concluded that foreign aid had a significantly positive impact on CLMV's economic growth between 1997 and 2014. Thus, it has been one of the successful strategies for poverty reduction in the sample countries in the ASEAN region.

As there are conflicting results in aid-growth literature in the past, while exploring the effectiveness of aid in many aid-recipient countries, it is necessary that further studies be conducted:

- To capture a bigger picture of aid effectiveness, with more countries in Asian continent covering a substantially longer period of time.

- Include other measures, such as mortality rate, enrolment rate, life expectancy, access to basic necessities such as water, food, electricity to determine the effectiveness of aid.

\section{References}

Boone, P. 1996. Politics and the effectiveness of foreign aid, European Economic Review, 40(2): 289-329.

Burnside, A. C., and Dollar, D. 2000. Aid, policies and growth, The American Economic Review, 90(4): 847-868.

Chenery, H. B., and Strout, A. M. 1966. Foreign assistance and economic development, The American Economic Review, 56: 679-733.

Collier, P., and Dollar, D. 2002. Aid allocation and poverty reduction, European Economic Review, 46: 475-1500, Elsevier.

Dalgaard, C. J., and Hansen, H. 2001. On aid, growth and good policies, Journal of Development Studies, 37: 17-41. 
Domar, E. D. 1946. Capital expansion, rate of growth, and employment, Econometrica, 14(2): 137-147. Retrieved from http://doi.org/10.2307/190536 4

Easterly, W. 2003. Can foreign aid buy growth? The Journal of Economic Perspectives, 17(3): 23-48.

Griffin, K. 1970. Foreign capital, domestic savings and economic development, Oxford Bulletin of Economics and Statistics, 32(2): 99-112.

Griffin, K., and Enos, J. 1970. Foreign assistance: Objectives and consequences, Economic Development and Cultural Change, 18(3): 313-327.

Gulati, U. 1978. Effect of capital imports on savings and growth in less developed countries, Economic Inquiry, 16(4): 563-569.

Gupta, K. L. 1975. Foreign capital inflows, dependency burden, and savings rates in developing countries: A simultaneous equation model, Kyklos, 28(2): 358-374.

Harrod, R. F. 1939. An essay in dynamic theory, The Economic Journal, 49 (193): 1433. Retrieved from http://doi.org/10.2307/2225181

Hatemi-J, A., and Irandoust, M. 2005. Foreign aid and economic growth: New evidence from panel integration, Journal of Economic Development, 30(1): 7180.

Hansen, H., and Tarp, F. 2001. Aid and growth regressions, Journal of Development Economics, 64(2): 547-570.

Islam, A. 1992. Foreign aid and economic growth: An econometric study of Bangladesh, Applied Economics, 24: 541-544.

Jensen, P.S., and Paldam, M. 2003. Can the new aid-growth models be replicated? Working Paper No. 2003-17, Institute for Economics: Aarhus.

Kao, C. 1999. Spurious regression and residual based tests for cointegration in panel data, Journal of Econometrics, 90(1): 1-44.

Kao, C. and Chiang, M. 2000. On the estimation and inference of a cointegrated regression in panel data', in Baltagi B. H. (ed.), Advances in Econometrics: Nonstationary Panels, Panel Cointegration and Dynamic Panels, Vol. 15, pp. $179-222$.

Karras, G. 2006. Foreign aid and long-run economic growth: Empirical evidence for a panel of developing countries, Journal of International Development, 18(7): 15-28.

Lee, G. 2007. Long run equilibrium relationship between inward FDI and productivity, Journal of Economic Development, 32(2): 183-192.

Levy, V. 1988. Aid and growth in the Sub-Saharan Africa: The recent experience, European Economic Review, 32: 1777-1795.

Levin, A., Lin, C. F., and Chu, C. S. J. 2002. Unit root tests in panel data: Asymptotic and finite-sample properties, Journal of Econometrics, 108: 1-24.

Mitra, R. 2013. Foreign aid and economic growth: A cointegration test for Cambodia, Journal of Economics and Behavioural Studies, 5(2): 117-121.

Moreira, S.B. 2005. Evaluating the impact of foreign aid on economic growth: A cross-country study, Journal of Economic Development, 30(2): 25-49.

Montinola, G. R. 2007. When does aid conditionality work? Department of Political Science, University of California, Davis.

Over, M. 1975. An example of the simultaneous equations problem: A note on foreign assistance: Objectives and consequences, Economic Development and Cultural Change, 24: 751-756.

Pallage, S., and Robe, M. A. 2001. Foreign aid and the business cycles, Review of International Economics, 9: 641-672.

Papanek, G. F. 1973. Aid, foreign private investment, savings and growth in less developed countries, Journal of Political Economy, 81: 120-130. 
Pedroni, P. 1997. Fully modified OLS for heterogeneous cointegrated panels and the case of purchasing power parity', Department of Economics, Indiana University, Mimeo.

Pedroni, P. 1999. Critical values for cointegration tests in heterogeneous panels with multiple regressors, Oxford Bulletin of Economics and Statistics, Special Issue, 61: 653-670.

Pedroni, P. 2000. Fully modified OLS for heterogeneous cointegrated panels. Advances in Econometrics, 15, 93-130.

Rostow, W. W. 1960. The five stages of growth: A summary, The stages of economic growth: A Non-Communist Manifesto, Cambridge: Cambridge University Press. pp. 4-16. Retrieved from https://www.ou.edu/uschina/gries/articles/IntPol/Ros tow.1960.Ch2.pdf

Sahin A. and Cengiz S. 2011. The real exchange rate and the employment market: Panel cointegration analysis of evidence from Turkey, African Journal of Business Management. Retrieved from http://www.academicjournals.org/jour nal/AJBM/article-abstract/525E5E624317

Smith, A. 1776. An inquiry into the nature and causes of the wealth of nations ( $1^{\text {st }} \mathrm{ed}$.), London: W. Strahan. Retrieved from https://books.google.com.kh/books?id=mt1 SAAAAcAAJ\&pg $=$ PP4\&redir_esc $=y \# v=$ twopage $\& q \& \mathrm{f}=$ true

Stock, J. and Watson, M. 1993. A simple estimator of cointegrating vectors in higher order integrated systems, Econometrica, 61(4): 783-820.

The World Bank 2014. Net official development assistance and official aid received (current US\$), Retrieved from http://data.worldbank.org/indicator/DT.OD

Vanessa-Cheung, V.. 2013. The Harrod-Domar Model Explained. ROM Economics, Retrieved from http://www.romeconomics.com/harrod-domar-model-explained/.

Veiderpass, A. and Andersson, P. 2007. Foreign aid, economic growth and efficiency development, Swedish Agency for Development Evaluation, Karlstad, Sweden.

Weisskopf, T. E. 1972. The impact of foreign capital inflow on domestic savings in under developed countries, The Journal of International Economics, 2(1): 25-38.

Winch, D. 2013. Adam Smith's theory of economic development: Our problems and his, Institute of Intellectual History, University of St Anders, Retrieved from http://www.intellectualhistory.net/winch/donald-winch-adam-smithstheory-of-economic-development-our-problems-and-his.pdf 